\title{
Emergence of Plecoptera in two lotic habitats in the Oulanka National Park, northeastern Finland
}

\author{
K. Kutusela'
}

The samples of emerging stoneflies obtained using slit traps indicated a three-phase course of emergence : early spring (two winter stoneflies), early summer (especially Perloidea) and autumn (a few abundant Nemouroidea). Early June and middle August are recommended as the sampling periods for benthon as far as stoneflies for bio-index studies are concerned.

\section{Emergence des Plécoptères de deux habitats lotiques dans le Parc National Oulanka (Nord-Est de la Finlande).}

Des Plécoptères ont été capturés à l'émergence grâce à un piège à fente. Trois phases d'émergences se succèdent au cours de l'année : début du printemps (deux Plécoptères hivernaux), début de l'été (surtout des Perloidea) et automne (quelques Nemouroidea abondants\}. Le début du mois de juin et la mi-août sont les meilleures périodes pour les prélèvements benthiques lorsqu'on veut utiliser les Plécoptères pour des calculs d'indices biotiques.

\section{1. - Introduction}

The flight periods of stoneflies in Finland have been summarized by Meinander (1965) using quite miscellaneous source material. As he himself notes, this makes the results incomplete. Also his monthlybased timetable, although widely used (e.g. Brinck 1949, Mendl \& Müller 1974, Zwick 1977), makes this kind of description superficial, еven though it does reveal the major latitudinal differences. It is important to know about this spatial variation, of course, because the correct timing of benthon sampling is a question of time and money in monitoring investigations, and Plecoptera is one of the key taxa in many bio-index methods (see Persoone \& De Pauw 1979) adopted in such studies.

The present work is based on material from two lotic habitats. The aim is to present faunistic results and the seasonal course of emergence in general, as shown by five years sampling, and to examine the applicability of this to benthic studies.

1. Department of Zoology, University of Oulu, PL 191, SF-90101 Oulu 10, Finland.

\section{2. - Study areas}

The work has been taking place close to the Oulanka Biological Station $\left(66^{\circ} 22^{\prime} \mathrm{N}, 29^{\circ} 18^{\prime} \mathrm{E}\right)$. Two different habitats, which are in a good natural state, are included : the main river Oulankajoki, and a tributary, the small stream Rytipuro. The study locations are $2.4 \mathrm{~km}$ apart.

Oulankajoki is $50.100 \mathrm{~m}$ wide in its riffle areas, the daily discharge values ranging between $4.5-350 \mathrm{~m}^{3} / \mathrm{sec}$ (Hyvärinen \& Gürer 1976). The water is very soft (approximately $1^{\circ} \mathrm{dH}$ ), neutral and fairly clear (only at spring floods and summer high water is $50 \mathrm{mgPt} / \mathrm{l}$ exceeded) (Myllymaa 1979). The substrate at the site consists mainly of boulders and large stones. The Pinus forest extends to the banks of river, where deciduous plants grow in a narrow band. The autotrophy of the river, however, finds its expression in the meagre littoral vegetation and mosses (Fontinalis spp.) and the filamentous algae on the rocks.

Rytipuro is $1.2 \mathrm{~m}$ wide and very shallow, with many alcoves and hollows in its stony bottom. The stream can dry up temporarily, as it did in the warm summer of 1980 . Its drainage area is $3.6 \mathrm{~km}^{2}$, including a small lake of approx. four hectares in its headwaters, and its total drop is $100 \mathrm{~m}$. The gradient at 
the site itself is $3 \%$. The forest canopy shades the stream completely. Heterotrophy is thus apparent, particularly as there is no macroepiphyton on the stones. The water is rather similar to that of the main river.

The weather conditions are rather well characterized by the following parameters, calculated from data for Kuusamo (Anon. 1978-1982), $45 \mathrm{~km}$ further south. The deviations of the monthly mean tempe. rature in June from the normal mean $\left(11.5^{\circ} \mathrm{C}\right.$ during 1931-60) were $-0.5,+1.0,+4.0,-1.5$ and $-4.5^{\circ} \mathrm{C}$ in the years concerned, and the effective temperature sums (sums of degrees over $5^{\circ} \mathrm{C}$ in the daily mean) at the end of June and for the whole year were : $233.8 / 698.4,269.3 / 870.7,365.4 / 915.2,221.6 /$ 757.4 and $116.6 / 664.4^{\circ} \mathrm{C}$. The value for June correlates well with the temperature deviation. The con. sistent differences between the sums for June and for the whole season, on the other hand, indicate that the temperature conditions during the rest of the summer were fairly similar each year.

\section{3. - Material and methods}

Two slit traps, as described by Kuusela \& Pulkkinen (1978), were positioned on the bank at each site, and were usually examined once or twice a week. The basic timeta. ble unit used here is the week, however.

Floodwaters, reindeer and tourists caused occasional damage to the traps, but this did not seem to have any essential effect on the faunistic results, even though it must have reduced the total numbers recorded. Since the periods of work of the research assistants at the Oulanka Biological Station changed yearly, the starting and finishing times of the sampling were not uniform. The material of 3504 stoneflies (listed on a yearly basis in Table 1) was trapped in $1978-82$ as follows : $22.5 .-16.11 .1978,28.5 .+30.10 .1979$, $27,5 .-20.10 .1980,5.5 .-14.10 .1981$ and $2.6,-20.9 .1982$. The sarnpling periods (1-25) are combined to start from the fifth of May onwards

\section{4. - Results}

\section{Faunas and communities}

A total of 21 species were identified (Table I), and the increment in species after the first year (which

Table I. - Species list and numbers of stoneflies caught each year and in total from the habitats studied. $\mathrm{O}=$ Oulankajoki, $\mathrm{R}=$ Rytipuro, $\mathbf{N}=$ number of individuals, $\mathbf{S}=$ number of species, $\mathbf{S}_{\mathbf{t}}=$ total number of species reached af ter each year.

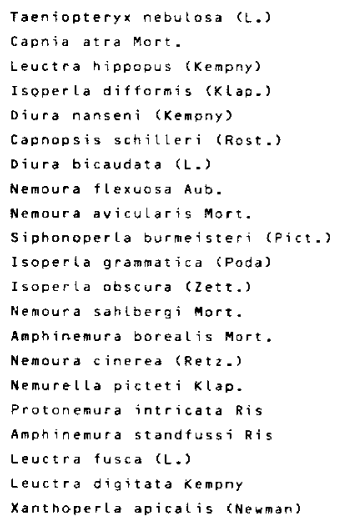

$\mathrm{N}$
$\mathrm{S}$
$\mathrm{S}$

\begin{tabular}{|c|c|c|c|c|c|c|c|c|c|c|c|}
\hline \multicolumn{2}{|c|}{1978} & \multicolumn{2}{|c|}{1979} & \multicolumn{2}{|c|}{1980} & \multicolumn{2}{|c|}{1981} & \multicolumn{2}{|c|}{1982} & \multicolumn{2}{|c|}{ TOTAL } \\
\hline 0 & $R$ & 0 & R & 0 & $R$ & 0 & $R$ & 0 & $\mathrm{R}$ & 0 & R \\
\hline 7 & 16 & 4 & 4 & & 6 & 15 & 1 & 3 & & 15 & 27 \\
\hline 141 & 13 & 18 & 3 & & 35 & 21 & 24 & 11 & 9 & 191 & 84 \\
\hline 53 & 2 & 12 & & & & 9 & & 2 & & 76 & 2 \\
\hline 38 & & 6 & & & & 1 & & & & 45 & \\
\hline 1 & 19 & & 2 & & 15 & 1 & 4 & & 10 & 2 & 50 \\
\hline 44 & 2 & II & & & 3 & 1 & & 2 & & 58 & 5 \\
\hline & 8 & & 1 & & 2 & & 18 & & & & 29 \\
\hline 35 & 1 & 4 & & & 7 & 2 & & & 1 & 41 & 9 \\
\hline 26 & & 9 & & 32 & & 2 & & 5 & & 74 & \\
\hline 8 & 1 & 3 & & 4 & & 1 & & 11 & & 27 & 1 \\
\hline 28 & 1 & 12 & & 9 & 3 & 3 & 1 & 57 & & 109 & 5 \\
\hline & 1 & & 15 & & 18 & & 41 & & 13 & & 88 \\
\hline 13 & & 3 & & 11 & & 7 & & 23 & & 57 & \\
\hline 3 & 36 & & 29 & & 48 & & 60 & 16 & 69 & 19 & 242 \\
\hline & & & 3 & & & & 1 & & 1 & & 5 \\
\hline & 3 & & 2 & & 3 & & 21 & & & & $2 \mathrm{G}$ \\
\hline & 311 & & 295 & & 1 & & 69 & & 23 & & 699 \\
\hline 338 & 2 & 170 & 2 & 7 & 3 & 152 & 2 & 20 & & 587 & g \\
\hline & & 2 & 2 & & & 2 & 1 & & & 4 & 3 \\
\hline & & & & & & 1 & & & & 1 & \\
\hline 735 & 416 & 254 & 358 & 63 & 144 & 1015 & 243 & 150 & 126 & 2217 & 1287 \\
\hline 13 & 14 & 12 & 11 & 5 & 12 & 15 & 12 & 10 & 7 & 16 & 16 \\
\hline & 17 & & 19 & & 19 & & 21 & & 21 & & 21 \\
\hline
\end{tabular}


gave 17) was low. Even the poorest year gave 15 species.

The habitats are identical in species number (16), but the communities differ markedly, with many species having a considerable or total preference for one habitat or the other (Table I). Thus $T$. nebulosa, C. atra, all three Isoperla species, both Diura species, $S$. burmeisteri, A. borealis and $L$. fusca are 'river species', and $C$. schilleri, and three Nemoura species, $P$. intricata and $A$. standfussi are 'stream species'.
Only L. hippopus may be said to be common to both habitats.

\section{General course of emergence}

The weekly number of stoneflies caught varies greatly within seasons and from one year to another. Close scrutiny of Fig. 1, however, shows that there are three active phases of emergence, in spring, early summer and autumn.

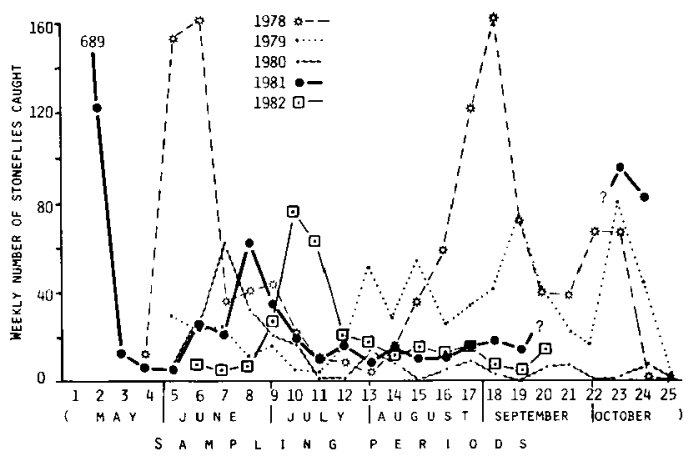

Fig. 1. General course of emergence of stoneflies each year, expressed as the weekly stum of individuals from both habitats. The symbols on the time-scale indicate an effective temperature sum of $300^{\circ} \mathrm{C}$.

The timing of the quite pronounced early summer maximum varies within a range of over a month, while the autumn maximum occupies an even longer period and is more irregular. Between these two phases there is a conspicuous decline in July.

The timing of early summer peak tends to be related to the temperature conditions after the spring as seen in Fig. 1, and it is only in 1980 that the peak is situated in the 'wrong' place as compared with the mean temperature for June or the effective temperature sum by the end of that month.

\section{Enrichment in species number}

The number of species recorded increases rapidly after May (Fig. 2), so that a total of more than ten species is reached within the first three weeks of June (except in 1982, the coldest summer). By the middle of July at least 13 species have been trapped every year, sometimes as many as 16 . After stationary phase in the enrichment curves in July the remaining third of the species start to emerge in August. 


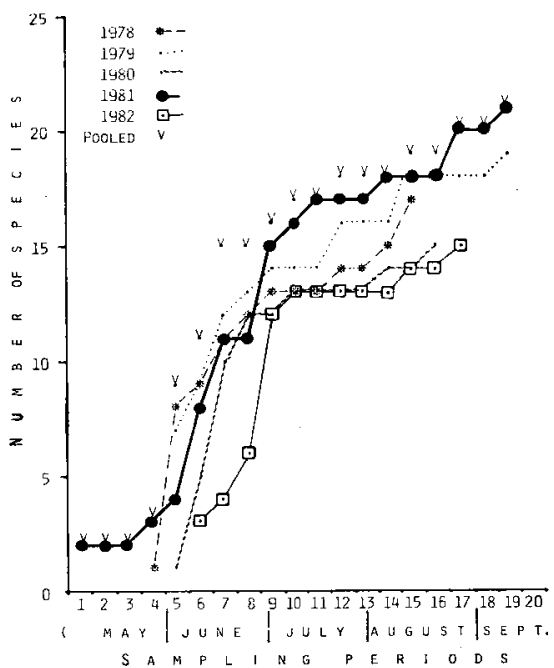

Comparison of the species increments in the two habitats shows the actual numbers per habitat to be smaller than in pooled material examined above (only 6 to 13), but in relative terms the curves take the same form as in Fig. 2.

\section{Emergence of species}

Fig. 3. presents the timetable of emergence for each species, based on the presence-absence data. As was expected from the number of individuals (Fig. 1) and the enrichment of species (Fig. 2), there exist a group of species which have a fairly concurrent start and short duration of emergence in June (the cold summer of 1982 being reflected in the late records for these early summer species). There are also some species which emerge over long periods of time, e.g. $N$. cinerea and $A$. standfussi.

The short type of emergence pattern is primarily characteristic of the Perlodidae, while the more protracted pattern is proper to the Nemouroidea.
Fig. 2. Species increment in the course of sampling, annually and in total (= pooled).

\section{5. - Discussion}

The samples yielded 21 out of the 34 species known in Finland (Meinander 1980). I. difformis and $P$. intricata are new records for the biogeographical province of Kuusamo (Ks), where 25 species have now been listed (cf. Meinander 1965). The enrichment of species in the course of the study was rapid, and even one year's sampling by this slit trap method produced all 21 species recorded. It is quite possible that the missing four species do not live in the habitats studied. There are many other types of habitat in the vicinity, however, so that migrating stoneflies may sometimes enrich the species number. The method seems to be safe for qualitative investigations at any rate.

Each of the habitats had one dominant species, which emerged in August and September. A. standfussi is generally known to live in streams with detritus accumulations on the bottom, as in Rytipuro (see Brinck 1949, Kamler 1967, Lillehammer 1975), whereas $L$. fusca inhabits rivers, where it feeds on auto- 


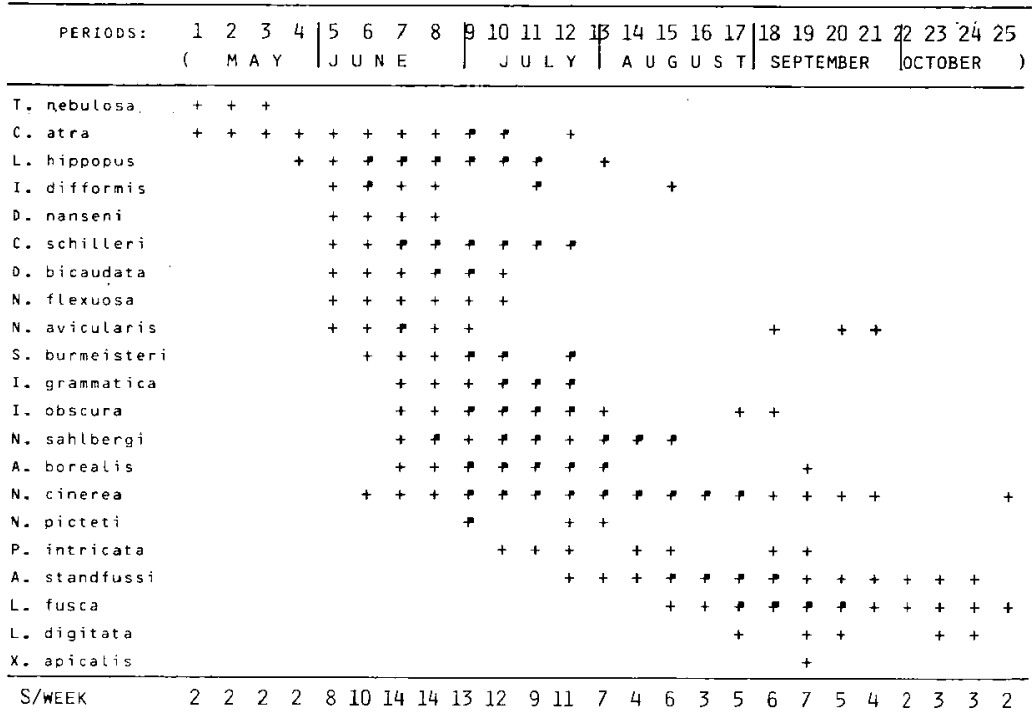

Fig. 3. Presence $(+)$ of species in the pooled material by sampling period. The cold summer of 1982 is indicated with a square in the right upper corner of the $+. S=$ number of species.

trophic vegetation growing on stones (Hynes 1941, Brinck 1949).

The communities differ markedly with respect to their species assemblages. This is indicated also by the proportion of predatory Perloidea : seven species in Oulankajoki, accounting for $17,6 \%$ of the individuals, against four in Rytipuro (1\%). This great majority of Nemouroidea in Rytipuro is in keeping with the heterotrophic nature of this habitat.

If the spring emergence of $T$. nebulosa (an abun. dant inhabitant of Oulankajoki, but not reliably sampled here) is included, the stonefly communities emerge in three phases. The clear passive period in July is an exceptional phenomenon not mentioned earlier in the literature. Thus the stonefly communities of Messaure (Mendl \& Müller 1974) and Lunz (Zwick 1977) emerge in a single-peaked pattern, June or July being the most active time in the former dis- trict, depending on the type of habitat, and May or July in the latter, depending on the year and stream. In these cases, however, a passive period may be obscured by the monthly basis of the timetables. Hints of a midsummer decline are seen only in the material of Kerst \& Anderson (1974), if their diagrams presenting species-specific results are combined.

Harper \& Pilon (1970) describe a synchronous and an extended emergence pattern. These types are convincingly represented in this study, too.

The bulk of the species emerge synchronously in June, when the peak in individual numbers is more pronounced than in autumn, which features some irregularities. Examination of the number of species per week is insufficient to observe the three-peaked course of emergence, the spring emergence dropping out and the autumn phase becoming unclear. Characteristically, the spring and autumn peaks 
consist of only a few species, but in great abundance. The real form of the annual course of emergence thus rest on the numbers of winter and autumn stoneflies. As has been experienced here, and by Illies (1973) and Zwick (1977) in particular, stonefly populations show major annual variations, in addition to which there exist the important question (not to be answered here) of whether there would be any stonefly species to replace $T$. nebulosa, $A$. standfussi and $L$. fusca if these were absent from the habitats studied here.

The prompt start of emergence in June and its synchronized pattern imply that the photoperiod may be an initiating factor. The timing of the early summer peak was rather closely related to the temperature conditions up until July, however, and cold weather was seen to have a retarding effect, as also described by Elliot (1967), Harper \& Pilon (1970), Lillehammer (1975), Kuusela (1976), for instance. These two factors evidently interact, with the photoperiod preventing the species from emerging too early in spring or too late in autumn. As far as the autumn species are concemed the problem is still very open in general, however.

Stoneflies are nowadays accorded an essential status as biological systems indicating the state of watercourses (see Persoone \& De Pauw 1979), and it is usually important to record the number of species from macrobenthon samples. Since most species leave their habitat before July, whereas the winter stoneflies will only be big enough to detect in August, two sampling periods are needed in bioindex studies : the early part of June and the middle of August. In principle, it should be possible to record all the stonefly species inhabiting the bottom by sampling at these times. For the present this recommendation as such is valid for the regional purposes only, but the general principle obviously also operates on a broader scale.

\section{Acknowledgements}

I would like to thank Dr. Juha Viramo, the warden of the Oulanka Biological Station for the excellent working facilities and practical help he has given me during this study. The language of this paper has been revised by Mr. Malcolm Hicks, M.A.

\section{References}

Anonymous. 1978.1982. - Ilmatieteen laitos. Kuukausikatsaus Suomen ilmastoon, $\mathrm{nr}$ 72-76. [Monthly weather report in Finland, nr 72-76] (in Finnish)

Brinck (P.). 1949. - Studies on Swedish Stoneflies (Plecoptera). Opusc. entomol. Suppl. 1 I: 1-250.

Elliott (J.M.). 1967. - The life histories and drifting of the Plecoptera and Ephemeroptera in a Dartmoor stream. J. Anim. Ecol. $36: 343-362$.

Harper (P.P.) \& Pilon (J.G.). 1970. - Annual patterns of emergence of some Quebec stoneflies (Insecta : Plecoptera). Can. J. Zool. 48: $681-694$.

Hynes (H.B.N.). 1941. - The taxonomy and ecology of the nymphs of British Plecoptera, with notes on the adults and eggs. Trams. $R$. ent. Soc. Lond. 91 : 459-557.

Hyvärinen (V.) \& Gürer (I.). 1976. - Statistical analysis of discharge data. I Duration curves of discharge. II Monthly mean and extreme discharges. Public. Water Res. Inst. 15, Natl Board of Waters.

Illies (J.). 1973. - Emergenzschwankungen - ein produktions biologisches Problem. Verh. Ges. Oköl., Saarbrücken, 1973:131-142.

Kamler (E.). 1967. - Distribution of Plecoptera and Ephemeroptera in relation to altitude above mean sea level and current speed in mountain waters. Pol. Arch. Hydrobiol. $14: 29-42$.

Kerst (C.D.) \& Anderson (N.H.). 1974. - Emergence patterns of Plecoptera in a stream in Oregon, USA. Freshwat. Biol. $4: 205-212$.

Kuusela (K.). 1976. - On emergence biology of Taeniopteryx nebulosa (L.) (Plecoptera). Ann. entomol. fenn. 42: 121-132.

Kuusela (K.) \& Pulkkinen (H.). 1978. - A simple trap for collecting newly emerged stoneflies (Plecoptera). Oikos 31 : 323-325.

Lillehammer (A.). 1975. - Norwegian stoneflies, II. Distribution and relationship to the environment. Norsk entomol. Tidsskr. 21: $195-250$

Meinander (M.). 1965. - List of Plecoptera of Eastern Fennoskandia. Fauna fenn. $19: 1.38$.

Meinander (M). 1980. - Suomen koskikorennot. Finlands bäcksländor (Plecoptera). Notul. entomol. 60:7.10.

Mendl (H.) \& Müller (K.). 1974. - Die Plecopteren des MessaureGebietes. Entomol. Tidsskr. 95; 129-147.

Myllymaa (U.). 1979. - The present state of the watercourses in Kuusamo, in : Studies on the natural environment of the Kutsamo district, northeastem Finland: 167-174. Acta Univ. Ouluensis Ser. A, Sci. Rer. Nat. No. 68 (Finnish with English abstract).

Persoone (G.) \& De Pauw (N.). 1979. - Systems of biological indjcators for water quality assessment, in : O. Ravera (ed.). Biological aspects of freshwater pollution : 39-75.

Zwick (P.) 1977. - Plecopteren-Enrergenz zweier Lunzer Bäche, 1972-1974. Anch. Hydrobiol. 80 : 458-505. 